\title{
Prognostic value of cathepsin D in breast cancer: comparison of immunohistochemical and immunoradiometric detection methods
}

\author{
U-J Göhring, A Scharl, U Thelen, A Ahr, G Crombach, B R Titius
}

\begin{abstract}
Aim-To test whether immunoradiometric or immunohistochemical detection of lysosomal protease cathepsin $D$ in breast cancer is more predictive of outcome.

Methods-Tumour tissues from 270 primary breast cancer patients were evaluated for the expression of cathepsin $D$ using immunohistochemistry (IH; paraffin embedded tissues) and an immunoradiometric assay (IRMA; cytosol from frozen tissues). Immunohistochemical scores were based on immunoreaction in tumour cells and tumour associated macrophages. Results-IRMA values (cut off $40 \mathrm{fmol} / \mathrm{mg}$ cell protein) correlated significantly with IH values. Recorded incidences of positive immunoreaction in tumour cells using two different cut off values were $52 \%$ and $35 \%$, respectively. Macrophages stained positive in $31 \%$ of tissues. Combined evaluation of tumour cells and macrophages resulted in positivity rates of $59 \%$ and $48 \%$, respectively. Node status was the only variable found to correlate with cathepsin D expression. IH results correlated significantly with clinical outcome (median observation time 68 months) in node negative patients $(n=120)$ but not in node positive patients $(n=145)$. Cathepsin $D$ positivity as measured by IRMA was not related to clinical outome in either group. On multivariate analysis in the node negative group, IH detection of cathepsin D appeared to be the only independent factor indicating prognosis. For node positive patients, tumour grade, size, and receptor status were of prognostic relevance.
\end{abstract}

University of Cologne, Cologne, Germany: Department of Obstetrics and Gynaecology U-J Göhring A Scharl

U Thelen A Ahr

G Crombach

Department of Pathology B R Titius

Correspondence to: Dr U-J Göhring, Department of Obstetrics and Gynaecology, University of Cologne, Kerpener Straße 34, D-50931 Köln, Germany.

Accepted for publication 20 July 1995

Proteases are involved in neoangiogenesis, invasive growth, and metastasis of carcinomas. ${ }^{1-3}$ The overexpression of the lysosomal protease cathepsin $\mathrm{D}$ is currently being investigated as a prognostic marker in node negative breast cancer patients. ${ }^{4-14}$
In 1979 Westley and Rochefort ${ }^{15}$ described the purification of a glycoprotein fraction (cathepsin D) from oestrogen stimulated, oestrogen receptor (ER) positive MCF-7 breast cancer cells. In cells of the mammary gland the enzymatically inactive procathepsin D $\left(M_{r} 52\right.$ $\mathrm{kDa}$ ) is completely transformed into an intermediate product $\left(M_{r} 48 \mathrm{kDa}\right)$ consisting of the mature forms $\left(M_{\mathrm{r}} 34 \mathrm{kDa}\right.$ and $M_{\mathrm{r}} 14$ $\mathrm{kDa}) .^{1617}$ Only minimal amounts of procathepsin $\mathrm{D}$ are accumulated in benign epithelial cells, ${ }^{517}$ whereas carcinomatous tissues contain much higher levels. ${ }^{58-20}$ The overexpression of cathepsin D precursors causes an overloading of the lysosomal transport system. More procathepsin D is thereby secreted into the cytoplasm and out of the tumour cell. ${ }^{11718}$ The human cathepsin D gene is located at the outer end of chromosome $11 \mathrm{p}$ close to the haras proto-oncogene. ${ }^{21}$

At present cathepsin D is measured mainly by immunoradiometric assays (IRMA) in tumour cytosols ${ }^{5-7910121322-25}$ requiring fresh or deep frozen $\left(-70^{\circ} \mathrm{C}\right)$ tissue. Routine monitoring requires a method by which cathepsin $\mathrm{D}$ can be measured reliably and reproducibly in minute amounts of routinely processed tissues, as is the case in immunohistochemistry (IH). Recently some investigators, ${ }^{112225-28}$ including ourselves ${ }^{29}$ compared the results of cathepsin D detection using both these methods and reported concordance rates of approximately $70 \%$. However, a $30 \%$ discordance of results may make a difference when prognostic information is required.

The retrospective study reported here compares immunoradiometric measurement of cathepsin D in deep frozen tissue cytosols with immunohistochemical detection in formalin fixed and paraffin embedded surgical specimens of 270 primary breast carcinomas for their predictive value with regard to the clinical course of the disease. The aim was not to evaluate concordance rates but to assess the predictive potential of either method. On the basis of a subtle scoring system we provide evidence that the predictive value of immunohistochemistry may be superior to that of immunoradiometry.

\section{Methods}

We tested tissue specimens of primary, invasive, ductal breast carcinomas from 270 patients who had been treated surgically between 1983 and 1988 at the Department of Obstetrics and Gynaecology of the University of Cologne. 
Local treatment consisted of simple mastectomy $(n=171)$ or lumpectomy $(n=99)$ plus postoperative irradiation of the breast (linear accelerator: $50 \mathrm{~Gy}$ to the whole breast and a boost of $10 \mathrm{~Gy}$ to the tumour bed). In 265 patients, axillary lymphadenectomy was performed up to level II, removing at least 10 nodes. No adjuvant treatment was given to node negative patients. Node positive, steroid receptor positive postmenopausal patients received adjuvant tamoxifen therapy (20-30 mg/ day for two to three years). Node positive premenopausal women, and node positive, receptor negative postmenopausal women received six cycles of adjuvant chemotherapy (cyclophosphamide/methotrexate/fluorouracil or epiadriamycin/cyclophosphamide). Follow up examinations were performed at regular intervals by our outpatient service or by cooperating gynaecologists in private practice. At present the median follow up period is 68 months (range 61-138 months).

Histological subtyping of tumours followed WHO guidelines (1981). Tumours were staged according to the TNM system of UICC. The histological grading was assessed according to the recommendations of Bloom and Richardson. Oestrogen receptors and progesterone receptors (PR) were detected and evaluated immunohistochemically as described previously $^{30}$ (ER: ERICA, Abbott; PR: mPR1, Dianova).

\section{IMMUNOHISTOCHEMISTRY}

Immunohistochemical detection of cathepsin $\mathrm{D}$ was based on the reactivity of monoclonal mouse antibody (His-Cath-Ab1: M1G8, Isotopen Diagnostik CIS) and a modified avidinbiotin complex method described by Hsu et $a l .{ }^{31}$ Specificity of the antibody was checked by western blot analysis: immunoreactive bands were located at the $52 \mathrm{kDa}, 48 \mathrm{kDa}$, and 34 $\mathrm{kDa}$ positions (procathepsin $\mathrm{D}$, intermediate and mature form). Reproducibility of immunohistochemical detection was tested by repeated staining of serial sections from 35 tumour specimens which produced nearly identical results. Positive and negative controls were used throughout each staining procedure. Macrophages were identified by use of a specific antibody (CD68).

Sections of $3-4 \mu \mathrm{m}$ thickness cut from routinely processed, formalin fixed (for up to 24 hours in neutral buffered formalin), paraffin wax embedded tumour tissues were mounted on glass slides, deparaffinised (30 minutes), and rehydrated in descending alcohol concentrations. After enzymatic digestion with trypsin $(0 \cdot 1 \%, 15$ minutes) the slides were incubated with primary antibody (1:50), bridging antibody (antimouse IgG 1:100, Vectastain BA 2000), and avidin-biotin complex (1:100, Vectastain Elite ABC-Kit PK 6100) for 30 minutes each in a moist chamber at room temperature. Between incubations slides were rinsed with phosphate buffered saline (PBS). Antigen-antibody complexes were visualised using diaminobenzidine (12 minutes). Hemalaun was used for counterstaining (two minutes).
Immunoreaction was assessed independently by two of us (U-JG, AS). Where discrepancies occurred results were re-evaluated and discussed until a final agreement was reached. Immunoreactivity of tumour cells (immunoreactive score $=$ IRS) was assessed by multiplying the percentage of positive cells (no positive cells $=0,<10 \%=1,10 \%-50 \%=2$, $>50 \%=3$ ) by staining intensity (weak $=1$, moderate $=2$, strong $=3$ ), which produced a 10 point scale (IRS $0-9$ ).

Immunoreactivity of tumour stroma (reaction $=R$ ) was evaluated on a four point scale ranging from 0 to $3(0=$ no positive stromal cells; $1=$ single stromal cells stained; $2=\mathrm{com}-$ bined staining of several stromal cells; $3=$ strong reaction). In order to find the most appropriate method of assessing immunohistochemical measurements of cathepsin D, tumours were qualitatively characterised as positive or negative using different cut off levels and varying combinations of immunoreactivity in tumour cells and stroma (table 1). These results were individually compared with the results of the immunoradiometric assay, related to clinical outcome (table 2), and then analysed statistically.

\section{BIOCHEMISTRY}

Cathepsin D concentrations were measured in 270 deep frozen tumour cytosols $\left(-70^{\circ} \mathrm{C}\right)$ which had been prepared for steroid hormone receptor determination between 1983 and 1988. However, in one case the amount of cytosol remaining was insufficient for cathepsin D measurement. The tumour tissues used for cytosol extraction and for immunohistochemistry, respectively, were adjacent parts of the same tumour sample. Tissue processing and cytosol extraction were performed according to the EORTC guidelines. ${ }^{32}$

Cathepsin D concentrations in cytosols were measured by an immunoradiometric assay (ELSA-CATH-D, Isotopen Diagnostik CIS) using a monoclonal antibody that recognises $52 \mathrm{kDa}$ procathepsin $\mathrm{D}$ and its $48 \mathrm{kDa}$ and 34 $\mathrm{kDa}$ secretion products. Cathepsin $\mathrm{D}$ concentrations $(\mathrm{fmol} / \mathrm{ml}$ ) were related to cytosol protein concentrations $(0.9-10.4 \mathrm{mg} / \mathrm{ml})$ measured according to Lowry et $a l,{ }^{33}$ and recorded in $\mathrm{pmol} / \mathrm{mg}$. The minimum detection limit of the assay was $200-300 \mathrm{fmol} / \mathrm{ml}$. The recovery rate ranged from $96 \%$ to $109 \%$ (540-2540 $\mathrm{fmol} / \mathrm{ml}$ ). The coefficients of the intra-assay ( $\mathrm{n}=4$ assays, $21-103 \mathrm{pmol} / \mathrm{mg}$ ) and interassay variance ( $\mathrm{n}=13$ assays, $23-118 \mathrm{pmol} / \mathrm{mg}$ ) were $3 \cdot 8 \%$ and $10 \cdot 1 \%$, respectively. A cathepsin D cytosol concentration of $40 \mathrm{pmol} / \mathrm{mg}$ was taken as the cut off limit. ${ }^{5}$

\section{STATISTICS}

Statistical analyses were performed using the software SPSS 5.0.2 for windows (Statistical Package for the Social Sciences; Munich). The Spearman rank test was used for comparison of the immunohistochemical and immuno- 
Table 1 Comparison of cathepsin $D$ detection by immunoradiometric assay (IRMA) and by immunohistochemistry (IH)

\begin{tabular}{|c|c|c|c|c|}
\hline IH & $n$ & $\begin{array}{l}\text { IRMA } \\
<40 \mathrm{pmol} / \mathrm{mg} \\
n \\
116(43 \%)\end{array}$ & $\begin{array}{l}\operatorname{IRMA} \\
\geq 40 \mathrm{pmol} / \mathrm{mg} \\
n \\
153(57 \%)\end{array}$ & Concordance \\
\hline $\begin{array}{l}\text { Evaluation } 1(\mathrm{E} 1) \\
\text { negative (tumour cells } \mathrm{IRS}=0 \text { ) }\end{array}$ & $130(48 \%)$ & 75 & 55 & \multirow{2}{*}{$\begin{array}{l}64 \% \\
\mathrm{r}=0.66 \\
\mathrm{p}<<0.001\end{array}$} \\
\hline positive (tumour cells IRS $\geq 1$ ) & $139(52 \%)$ & 41 & 98 & \\
\hline $\begin{array}{l}\text { Evaluation } 2 \text { (E2) } \\
\text { negative (tumour cells IRS } \leq 1 \text { ) }\end{array}$ & $174(65 \%)$ & 98 & 76 & \multirow{2}{*}{$\begin{array}{l}65 \% \\
\mathrm{r}=0.64 \\
\mathrm{p}<<0.001\end{array}$} \\
\hline positive (tumour cells IRS $\geq 2$ ) & $95(35 \%)$ & 18 & 77 & \\
\hline $\begin{array}{l}\text { Evaluation } 3 \text { (E3) } \\
\text { negative (stroma cells } R \leq 1 \text { ) }\end{array}$ & $185(69 \%)$ & 105 & 80 & \multirow{2}{*}{$\begin{array}{l}66 \% \\
r=0.65 \\
p<<0.001\end{array}$} \\
\hline positive (stroma cells $R \geq 2$ ) & $84(31 \%)$ & 11 & 73 & \\
\hline $\begin{array}{l}\text { Evaluation } 4(E 4) \\
\text { negative (IRS }=0 \text { and } R \leq 1 \text { ) }\end{array}$ & $109(41 \%)$ & 69 & 40 & \multirow{2}{*}{$\begin{array}{l}68 \% \\
\mathrm{r}=0.68 \\
\mathrm{p}<<0.001\end{array}$} \\
\hline positive (IRS $\geq 1$ and/or $R \geq 2$ ) & $160(59 \%)$ & 47 & 113 & \\
\hline $\begin{array}{l}\text { Evaluation } 5(\mathrm{E} 5) \\
\text { negative (IRS } \leq 1 \text { and } R \leq 1)\end{array}$ & $141(52 \%)$ & 92 & 49 & \multirow{2}{*}{$\begin{array}{l}73 \% \\
\mathrm{r}=0.69 \\
\mathrm{p}<<0.001\end{array}$} \\
\hline positive (IRS $\geq 2$ and/or $R \geq 2$ ) & $128(48 \%)$ & 24 & 104 & \\
\hline
\end{tabular}

radiometric data. Univariate analyses utilised the $\chi^{2}$ test. Follow up evaluations were based on $\log$ rank test ${ }^{34}$ and graphically visualised by Kaplan-Meier curves. Multivariate analyses used the Cox proportional hazards model by calculating relative risks. ${ }^{35}$

\section{Results}

Immunohistochemistry using a monoclonal mouse antibody (M1G8) on formalin fixed, paraffin embedded primary breast cancer tissues visualised cathepsin $\mathrm{D}$ as an intracytoplasmic granular staining in tumour cells and in "tumour infiltrating macrophages" (stromal cells) (for microphotographs see Göhring $\left.e t a l^{9}\right)$. Staining of tumour cells tended to be more intense towards the cell membranes. There was little intratumoral variation of staining intensity in positive tumour cells, whereas stromal cells varied considerably in this respect. Non-neoplastic peritumoral lobular or ductal epithelia showed no specific staining. The coexistence of cathepsin $\mathrm{D}$ positive tumour and stromal cells within a tumour was statistically highly significant $(p<<0.001)$. In only $7 \%$ of the examined tissues did we fail to observe any parallels between macrophage positivity and tumour cell immunoreactivity. The distribution of positive cells within tumour tissue was heterogeneous. By using evaluation formulae E1 (IRS 1) and E2 (IRS 2), 52\% and $35 \%$ of tumour tissue specimens were denoted positive. Immunoreaction in stromal cells (E3: R 2) was seen in $31 \%$ of tumours, while evaluations E4 (IRS 1 and/or R 2) and E5 (IRS 2 and/or R 2) yielded positivity rates of $59 \%$ and $48 \%$, respectively (table 1 ). Interobserver variation was low. In summary, assessment of immunoreaction by two independent investigators was

Table 2 Relationship of established prognostic factors and cathepsin D expression to disease-free survival (DFS) and overall survival (OS) for the total study group and for node negative and node positive patients (univariate analyses)

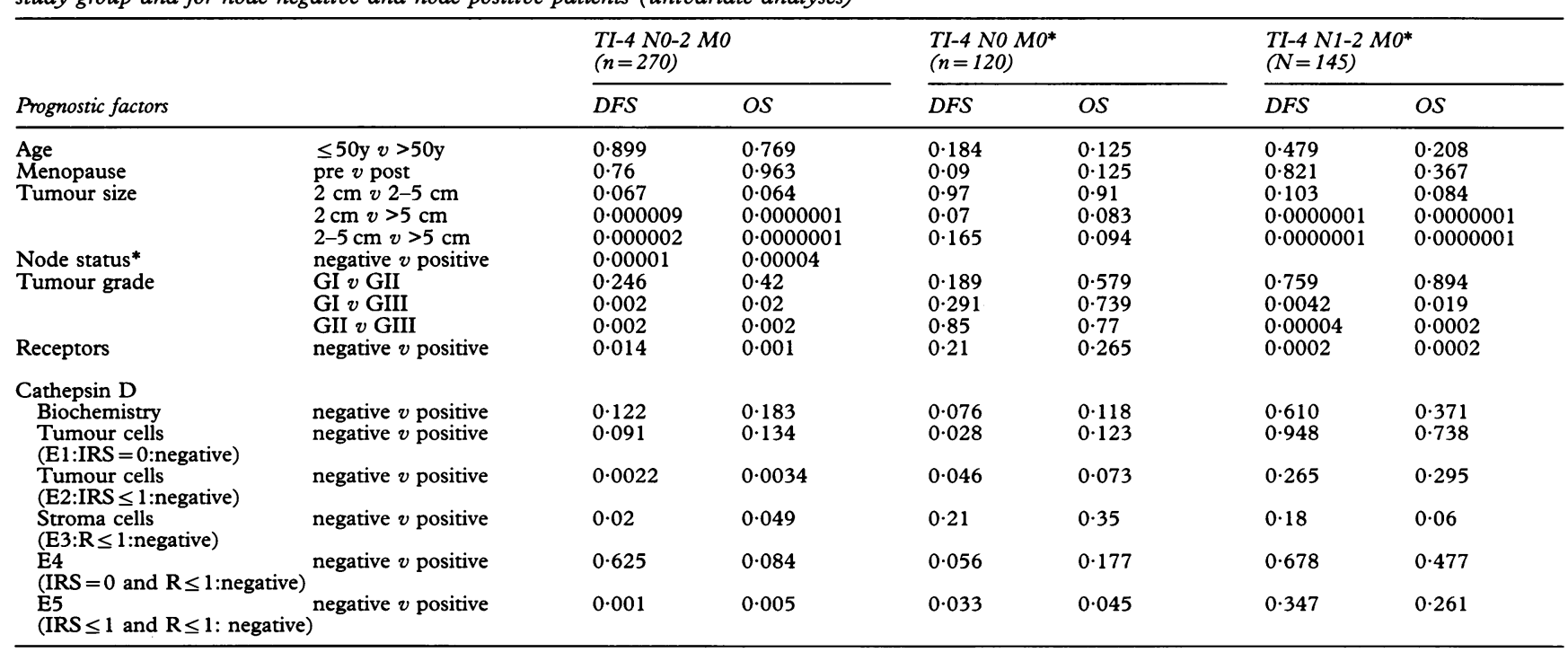

* Axillary lymphadenectomy was performed in 265 patients. E1-E5: different types of immunohistochemical evaluation. 


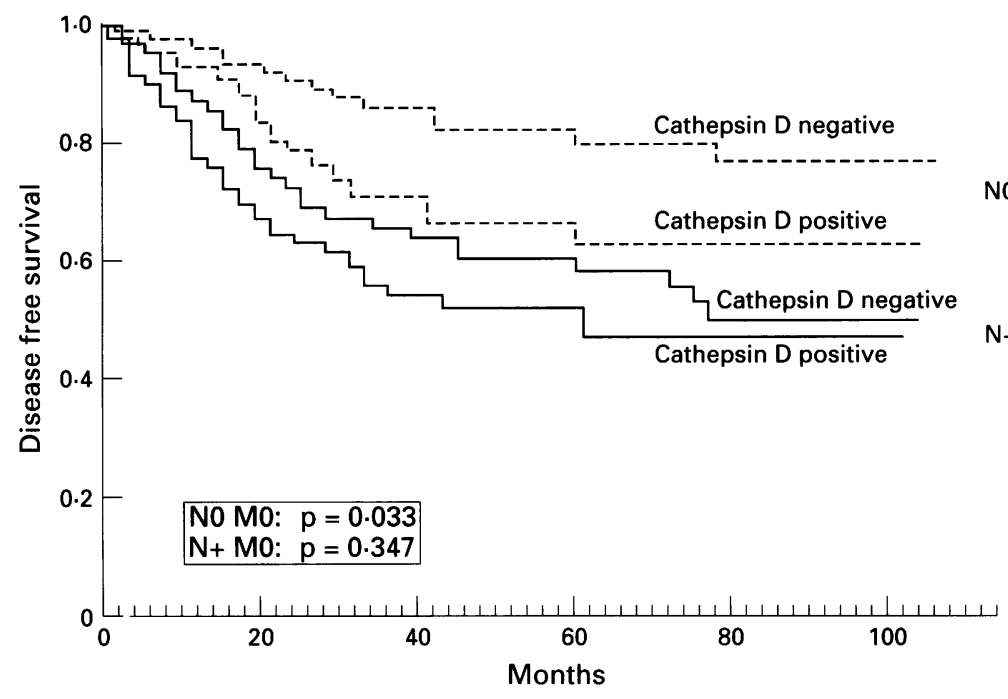

Figure 1 Kaplan-Meier curves for disease-free survival in node positive (continuous line) and node negative patients (broken line), subdivided according to immunohistochemical cathepsin D expression (evaluation formula E5).

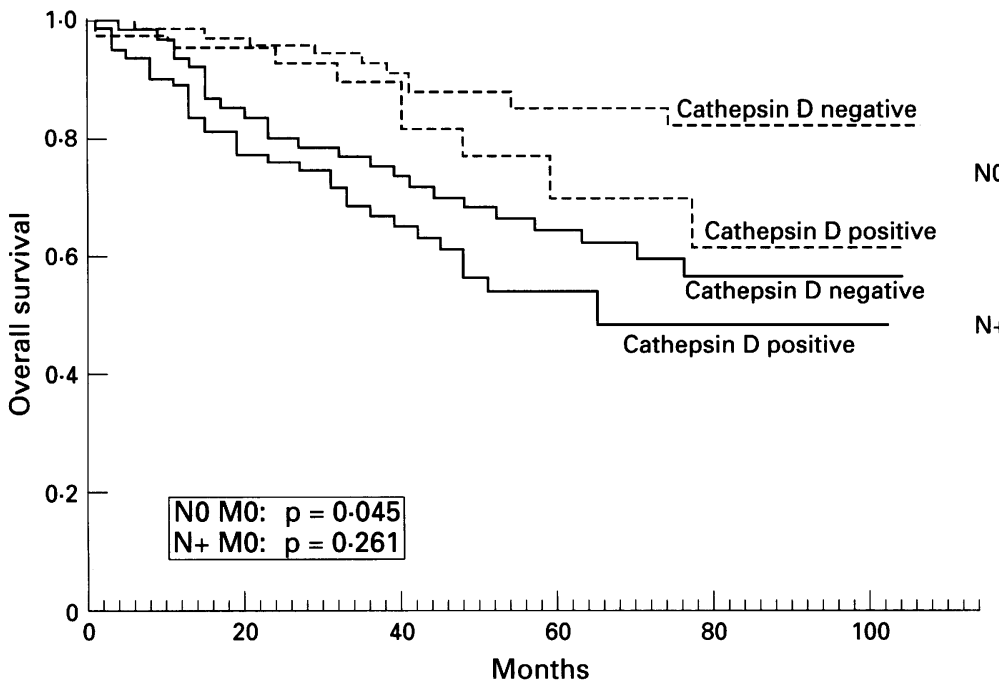

Figure 2 Kaplan-Meier curves for overall survival in node positive (continuous line) and node negative patients (broken line), subdivided according to immunohistochemical cathepsin $D$ expression (evaluation formula E5).

identical in $92 \%$ of tumours $(95 \%$ concordance for tumour cells, $89 \%$ concordance for stromal cells).

Immunoradiometric measurement of cathepsin $\mathrm{D}$ concentrations in tumour cytosols revealed values exceeding the cut off level $(40 \mathrm{pmol} / \mathrm{mg})$ in $57 \%$ of samples. The results of all the various immunohistochemical evaluations (E1-E5) correlated with the biochemical findings (concordance rates ranging from $64 \%$ to $73 \%$ ). Correlation was highest with E5 (table 1).

Patients in our study group had been diagnosed as having breast cancer between 1983 and 1988. Follow up was complete in 262 women. Median observation time was 68 months (61-138 months). Seven women died from causes other than breast cancer, with no evidence of disease; 165 women $(63 \%)$ were in complete remission; 90 women (34\%) had a recurrence, and 71 of the latter group (27\% of the total study group) died from their tu- mours. In the node negative group (120 patients, complete follow up in 117 patients, median observation time 71 months), three women died from other causes with no evidence of disease, $89(76 \%)$ had no evidence of disease, $25(21 \%)$ had a relapse, and $18(15 \%)$ of the latter group died from the disease. For the node positive group (145 patients, complete follow up in 141 patients, patients, median observation time 48 months) the corresponding figures were four deaths not related to breast cancer, 75 with no evidence of disease (53\%), 62 relapses $(44 \%)$, and 54 tumour related deaths $(38 \%)$.

Survival analyses (log-rank test using CoxMantel's $\chi^{2} \mathrm{p}$ value) showed tumour size and nodal status to be of high prognostic significance. In node negative patients none of the established prognostic indices bore any relation to survival rates (table 2). However, in the node positive group, tumour size, tumour grade, and steroid hormone receptor status were all significantly related to clinical outcome (table 2). With respect to immunoradiometric cathepsin D measurement, a weak correlation with prognosis (disease-free survival: $p=0.076$; overall survival: $p=0.118$ ) was found in node negative patients, but none at all in node positive patients (disease-free survival: $p=0.61$; overall survival: $p=0.371$ ). With respect to immunohistochemical cathepsin $\mathrm{D}$ detection, significant correlations with prognosis were found in node negative patients when evaluation E5 (disease-free survival: $p=0.033$; overall survival: 0.045 ) was used. For node positive patients none of the immunohistochemical evaluation criteria bore any relation to prognosis ( $p>0.05$ ) (table 2; figs 1 and 2).

Further analysis was based on the E5 evaluation of the immunohistochemical findings, which correlated most closely with prognosis. Table 3 relates immunohistochemical expression of cathepsin D to established prognostic indices (that is, nodal status, tumour size, tumour grade, steroid receptor status, age, and menopausal status) in the total study group and in the node negative and node positive subgroups. Cathepsin D detection correlated with nodal status only $(p=0.006)$. For node negative patients stepwise Cox regression showed that tumour size, tumour grade, and hormone receptor status were of prognostic significance for disease-free survival and overall survival, whereas both immunoradiometric and immunohistochemical forms of cathepsin D expression were irrelevant (table 4). For node negative patients Cox regression showed that immunohistochemically detected cathepsin D expression had prognostic value (disease-free survival: $R R=2 \cdot 66, p=0 \cdot 034$; overall survival: $R R=2 \cdot 24, p=0.058$ ), while all the other indices tested were shown to be unrelated to survival (table 5 ).

\section{Discussion}

About $20-30 \%$ of node negative patients have a relapse and eventually die from breast cancer, whereas $70-80 \%$ survive. ${ }^{36-38}$ Choosing patients for adjuvant treatment, which has been 
Table 3 Correlation between classic prognostic factors and immunohistochemical cathepsin $D$ detection (evaluation formula E5) for the total study group and node negative and node positive sub-groups

\begin{tabular}{|c|c|c|c|c|c|c|c|c|c|c|}
\hline & & \multicolumn{3}{|c|}{$\begin{array}{l}T I-4 \text { NO-2 MO } \\
(n=270)\end{array}$} & \multicolumn{3}{|c|}{$\begin{array}{l}T I-4 \text { NOMO* } \\
(n=120)\end{array}$} & \multicolumn{3}{|c|}{$\begin{array}{l}T I-4 N 1-2 M 0^{*} \\
(N=145)\end{array}$} \\
\hline & & $\begin{array}{l}\text { Negative } \\
n\end{array}$ & $\begin{array}{l}\text { Positive } \\
n\end{array}$ & $p$ & $\begin{array}{l}\text { Negative } \\
n\end{array}$ & $\begin{array}{l}\text { Positive } \\
n\end{array}$ & $p$ & $\begin{array}{l}\text { Negative } \\
n\end{array}$ & $\begin{array}{l}\text { Positive } \\
n\end{array}$ & $p$ \\
\hline Age & $\begin{array}{l}\leq 50 \text { years } \\
>50 \text { years }\end{array}$ & $\begin{array}{l}54 \\
87\end{array}$ & $\begin{array}{l}38 \\
91\end{array}$ & $0 \cdot 126$ & $\begin{array}{l}31 \\
44\end{array}$ & $\begin{array}{l}13 \\
32\end{array}$ & $0 \cdot 171$ & $\begin{array}{l}23 \\
42\end{array}$ & $\begin{array}{l}24 \\
56\end{array}$ & 0.491 \\
\hline Menopause & $\begin{array}{l}\text { pre } \\
\text { peri } \\
\text { post }\end{array}$ & $\begin{array}{l}46 \\
14 \\
81\end{array}$ & $\begin{array}{l}28 \\
12 \\
89\end{array}$ & $0 \cdot 113$ & $\begin{array}{r}25 \\
8 \\
42\end{array}$ & $\begin{array}{r}10 \\
4 \\
31\end{array}$ & 0.360 & $\begin{array}{r}21 \\
5 \\
39\end{array}$ & $\begin{array}{r}17 \\
8 \\
55\end{array}$ & 0.316 \\
\hline Tumour size & $\begin{array}{l}2 \mathrm{~cm} \\
2-5 \mathrm{~cm} \\
>5 \mathrm{~cm}\end{array}$ & $\begin{array}{l}56 \\
71 \\
14\end{array}$ & $\begin{array}{l}41 \\
67 \\
21\end{array}$ & $0 \cdot 192$ & $\begin{array}{r}38 \\
34 \\
3\end{array}$ & $\begin{array}{r}22 \\
20 \\
3\end{array}$ & $0 \cdot 810$ & $\begin{array}{l}18 \\
36 \\
11\end{array}$ & $\begin{array}{l}19 \\
45 \\
16\end{array}$ & $0 \cdot 817$ \\
\hline Node status* & $\begin{array}{l}0 \text { positive } \\
1-3 \text { positive } \\
\geq 4 \text { positive }\end{array}$ & $\begin{array}{l}75 \\
42 \\
23\end{array}$ & $\begin{array}{l}45 \\
42 \\
38\end{array}$ & 0.006 & & & & & & \\
\hline Tumour grade & $\begin{array}{l}\text { I } \\
\text { II } \\
\text { III }\end{array}$ & $\begin{array}{l}24 \\
74 \\
43\end{array}$ & $\begin{array}{l}19 \\
71 \\
39\end{array}$ & 0.858 & $\begin{array}{l}14 \\
36 \\
25\end{array}$ & $\begin{array}{r}7 \\
31 \\
70\end{array}$ & 0.059 & $\begin{array}{r}9 \\
38 \\
18\end{array}$ & $\begin{array}{l}12 \\
37 \\
31\end{array}$ & 0.301 \\
\hline Receptors & $\begin{array}{l}\text { negative } \\
\text { positive }\end{array}$ & $\begin{array}{l}45 \\
96\end{array}$ & $\begin{array}{l}39 \\
90\end{array}$ & $0 \cdot 766$ & $\begin{array}{l}25 \\
50\end{array}$ & $\begin{array}{l}79 \\
36\end{array}$ & $0 \cdot 117$ & $\begin{array}{l}20 \\
45\end{array}$ & $\begin{array}{l}29 \\
51\end{array}$ & 0.488 \\
\hline
\end{tabular}

* Axillary lymphadenectomy was performed in 265 patients.

Table 4 Multivariate analysis for disease-free survival and overall survival in node positive patients $(n=141)$. The following variables were included: cathepsin $D$ detection by bio-chemistry (IRMA) and immunohistochemistry (IH) (evaluation formula E5), tumour size, tumour grade according to Bloom and Richardson, and steroid hormone receptor status

\begin{tabular}{|c|c|c|c|c|c|c|}
\hline \multirow[b]{2}{*}{$T 1-4 N 1-2 M 0$} & \multicolumn{3}{|c|}{ Disease-free survival } & \multicolumn{3}{|c|}{ Overall survival } \\
\hline & $p$ & Relative risk & ( $95 \%$ confidence interval) & $p$ & Relative risk & ( $95 \%$ confidence interval) \\
\hline $\begin{array}{l}\text { Tumour size } \\
\text { Tumour grade } \\
\text { Receptors } \\
\text { Cathepsin D IH } \\
\text { Cathepsin D IRMA }\end{array}$ & $\begin{array}{l}\ll 0 \cdot 001 \\
\mathbf{0 . 0 1 7} \\
\mathbf{0 . 0 4} \\
0 \cdot 25 \\
0 \cdot 62\end{array}$ & $\begin{array}{l}1 \cdot 8 \\
1 \cdot 7 \\
0 \cdot 6 \\
1 \cdot 37 \\
1 \cdot 15\end{array}$ & $\begin{array}{l}(\mathbf{1} \cdot 36-2 \cdot 39) \\
(\mathbf{1} \cdot \mathbf{1 0}-\mathbf{2} \cdot \mathbf{5 3}) \\
(\mathbf{0} \cdot \mathbf{3 8}-\mathbf{0} \cdot \mathbf{9 4}) \\
(0 \cdot 80-2 \cdot 37) \\
(0 \cdot 66-2 \cdot 00)\end{array}$ & $\begin{array}{c}\ll \mathbf{0 \cdot 0 0 1} \\
\mathbf{0} \cdot \mathbf{0 4} \\
0 \cdot 06 \\
0 \cdot 20 \\
0 \cdot 88\end{array}$ & $\begin{array}{l}2 \cdot 13 \\
1 \cdot 58 \\
0 \cdot 89 \\
1 \cdot 45 \\
1.05\end{array}$ & $\begin{array}{l}(\mathbf{1} \cdot 60-2 \cdot 84) \\
(1 \cdot 01-2 \cdot 36) \\
(0 \cdot 62-1 \cdot 11) \\
(0 \cdot 82-2 \cdot 57) \\
(0 \cdot 82-2 \cdot 57)\end{array}$ \\
\hline
\end{tabular}

Table 5 Multivariate analysis for disease-free survival and overall survival in node netative patients $(n=117)$. The following variables were included: cathepsin D detection by bio-chemistry assay (IRMA) and immunohistochemistry measurement (IH) (evaluation formula E5), tumour size, tumour grade according to Bloom and Richardson, and steroid hormone receptor status

\begin{tabular}{|c|c|c|c|c|c|c|}
\hline \multirow[b]{2}{*}{ T1-4 NO MO } & \multicolumn{3}{|c|}{ Disease-free survival } & \multicolumn{3}{|c|}{ Overall survival } \\
\hline & $p$ & Relative risk & ( $95 \%$ confidence interval) & $p$ & Relative risk & ( $95 \%$ confidence interval) \\
\hline Cathepsin D IH & 0.034 & $2 \cdot 66$ & $(1 \cdot 03-6 \cdot 85)$ & 0.058 & $2 \cdot 24$ & $(0 \cdot 99-6 \cdot 27)$ \\
\hline Receptors & $0 \cdot 21$ & 0.58 & $(0 \cdot 24-1 \cdot 37)$ & $0 \cdot 15$ & 0.49 & $(0 \cdot 18-1 \cdot 30)$ \\
\hline Tumour grade & $0 \cdot 26$ & $1 \cdot 5$ & $(0.75-2.99)$ & 0.24 & $1 \cdot 34$ & $(0 \cdot 80-2 \cdot 42)$ \\
\hline Tumour size & 0.37 & $1 \cdot 3$ & $(0 \cdot 76-2 \cdot 10)$ & 0.39 & 0.96 & $(0 \cdot 73-3 \cdot 25)$ \\
\hline Cathepsin D IRMA & $0 \cdot 52$ & $0 \cdot 8$ & $(0 \cdot 41-1 \cdot 58)$ & 0.63 & $0 \cdot 86$ & $(0 \cdot 48-1 \cdot 56)$ \\
\hline
\end{tabular}

shown to increase survival ${ }^{39}$ but may cause severe side effects, is always a challenging decision whereby the risk of overtreatment must be weighed against the probable benefits to certain patients. In recent years efforts have therefore been made to search out and test potential markers of prognosis in node negative patients. ${ }^{3637}$

Numerous reports including background research ${ }^{1315-182040-42}$ and other purely clinical studies $^{5-12} 14$ 23-25 27 28 43-45 have provided evidence for a correlation between cathepsin D overexpression and an increased tendency towards invasive growth and metastasis with poor clinical outcome. These observations may be explained by the proteolytic function of cathepsin $\mathrm{D}$, which is thought to facilitate tumour cell invasion by digestion of proteoglycanes of the interstitial matrix and basal membrane. ${ }^{118} \mathrm{An}$ additional autocrine mitogenic effect is the hypothesised mechanism by which this protease promotes metastasis. ${ }^{3}$ High concentrations of cathepsin $\mathrm{D}$ have been found in breast cancer cells and macrophages, especially in their endosomes where biologically active proteins are degraded. ${ }^{17}$ Mathieu et $a l^{41}$ described an intense interaction between cathepsin D and insulinlike growth factor-II (IGF-II) through which the mitogenic effect of IGF-II is enhanced even at low concentrations of cathepsin $\mathrm{D}$.

Up to now cathepsin D concentrations in tumours have been measured chiefly in cytosols, ${ }^{5-79101213234647}$ using a sandwich double determinant immunoassay (M1G8, D7E3). ${ }^{48}$ Preparation of cytosols requires a critical amount of tumour tissue exceeding $300-500 \mathrm{mg}$. The increasing frequency of small breast carcinomas demands techniques such as 
immunohistochemistry whereby predictors can be detected even in minimal amounts of tissue or in routinely fixed and processed surgical specimens. The ability to use stored specimens also allows retrospective testing of large groups of breast cancer patients. Moreover, immunohistochemistry has the major advantage of combining a topoanatomical localisation of cathepsin D with histological characterisation of reactive cells. It is therefore of considerable clinical interest to compare immunohistochemical detection methods for cathepsin $D$ with the established immunoradiometric assay.

Garcia et $a l^{2040}$ were the first to describe the immunohistochemical detection of cathepsin $\mathrm{D}$ in benign breast lesions and in breast carcinomas. In the meantime additional accounts of immunohistochemical cathepsin D detection in breast cancer have been published. ${ }^{481114222527-2943-4549-52}$ It is difficult to compare these studies because there are differences with respect to nodal status, the antibodies and the form of detection used, and the method of scoring. Using different cut off values, positivity rates in tumour cells varied between $36 \%{ }^{844}$ and $73 \%,{ }^{14}$ or in macrophages between $35 \%{ }^{8}$ and $89 \% .{ }^{45}$ These discrepancies may be explained, at least in part, by the use of different antibodies directed against different epitopes and by the heterogeneity of the study groups. They show the importance of devising a commonly accepted method of scoring.

A few studies have compared immunohistochemical and immunoradiometric methods of cathepsin D determination and reported a good correlation, ${ }^{112225-28}$ results that are confirmed by our data. However, these investigators did not discriminate between the two methods as to prognostic value and only one report ${ }^{25}$ was based on more than 100 tumour specimens.

The cathepsin D staining pattern in tumour cells, and "tumour infiltrating macrophages", which resembles the lysosomal localisation of the antigen and has also been described in other reports. ${ }^{4811} 14404344495052$ In some neoplasias the presence of tumour associated macrophages correlates with tumour invasion, tumour grade, and necrosis. ${ }^{53}$ In agreement with other study groups, ${ }^{811252845}$ we found a strong coexpression of cathepsin D in tumour cells and in stroma. The evaluation of positive tumour cells (E1, E2) is straightforward, whereas the assessment of tumour associated macrophages (E3) is harder, because a definitive histological classification of the latter can be difficult. This is reflected by the somewhat lower interobserver concordance for E3. Winstanley et $a l^{14}$ based their evaluation of cathepsin D overexpression on positive tumour cells only, and reported a comparably good interobserver concordance $(90 \%)$. The agreement between the assessments of different research assistants in Stonelake's group ${ }^{11}$ was also high at $91 \%$. In order to discriminate between varying degrees of antigen expression, staining intensity of tumour cells is recorded in the form of an immunoreactive score. We did not employ this score in tumour associated stroma because the distribution and staining intensity of positive macrophages varied considerably. Both tumour cells and macrophages should be evaluated as long as the function of cathepsin $\mathrm{D}$ positive macrophages in tumour neogenesis and tumour spread remains unclear and staining of stromal cells correlates with survival. Their combined evaluation (tumour cells or macrophages or both) according to formula E5, by which weak staining in sporadic tumor cells (IRS 1) and immunoreaction in single stromal cells ( $R$ 1) is recorded as negative, yielded the best correlation to IRMA and, more importantly, information on the clinical course of the disease.

Subjective error in the assessment of immunohistochemical staining is a major concern. Our group E 5 allowed clear characterisation of the majority $(79 \%)$ of tumours. In $32 \%$ of tumours a distinct absence of specific staining made a negative scoring unequivocal. On the other hand $47 \%$ of tumours shown a clear and immediately obvious positive immunoreaction. Cases with exclusively low immunoreaction in stromal cells $(9 \%)$ or with a tumour cell IRS $1(12 \%)$ are dubious and require more careful consideration.

When cathepsin D detection was compared with case history and tumour characteristics, we found no correlation between cathepsin D and age, menopausal status, or receptor status, thus confirming the results of other investigators. ${ }^{4434450}$ Like three other groups, 142745 we found the relation between cathepsin D expression and nodal status to be highly significant, but in contrast to Isola et $a l^{8}$ or Winstanley et $a l^{14}$ we did not find any correlation between cathepsin $\mathrm{D}$ expression and tumour size.

With respect to the prognostic value of immunohistochemical cathepsin $\mathrm{D}$ detection, the published results are equally confusing. In contrast to our findings, Têtu et $a l^{44}$ reported a significant correlation between disease-free survival of node positive patients and positive immunoreaction in stromal cells, from which they concluded that macrophages played a significant role in invasive tumour growth and metastasis. ${ }^{44}$ Kandalaft et $a l^{50}$ found no correlation between cathepsin $\mathrm{D}$ detection and survival in either node negative or node positive patients. Henry et $a l^{43}$ reported a significant relation between cathepsin $\mathrm{D}$ expression and disease-free survival in oestrogen receptor positive, node negative cases. Winstanley et $a l^{14}$ also showed a significant correlation between cathepsin D detection and overall survival, but only after univariate analysis. However, in their evaluations these investigators took no account of nodal status. In their study of stage I breast cancer patients, Armas et $a l^{4}$ also used univariate tests but found that cathepsin $\mathrm{D}$ expression was related to neither disease-free survival nor overall survival. Using univariate analysis Eng-Tan et $a l^{28}$ showed a correlation between immunohistochemically detected cathepsin D and disease-free survival but not overall survival in breast cancer patients; however, they failed to establish it as an independent prognostic factor. Isola et $a l^{8}$ detected strong correlations between cathepsin D expression 
and disease-free and overall survival in node negative patients using both univariate and multivariate analyses. In a group of 86 stageheterogeneous breast carcinomas Visscher et $a l^{45}$ found that neither stromal nor tumour cell positivity alone correlated with recurrence-free survival; however, additive staining in both compartments was strongly predictive in all patients and in the node positive subgroup. We confirmed these latter results. In an earlier report Tandon et al ${ }^{12}$ showed a significant correlations between cathepsin D expression and prognosis in node negative patients using univariate and multivariate analyses. However, recently this group ${ }^{54}$ failed to reproduce their findings when using western blot analysis and immunohistochemistry on cell pellets.

We present data that support the suggestion that immunohistochemical detection of cathepsin $\mathrm{D}$ could be used to identify patients with poor prognosis in the important group of node negative breast cancer patients. We have shown that the criteria on which the evaluation of immunohistochemical staining is based are most critical for a relevant linkage of immunohistochemical findings to clinical outcome. Our data should now be supplemented by prospective immunohistochemical studies with well defined and uniform criteria for evaluating immunoreactivity. To this end the scoring system presented in this report may be of value.

Tissues were courteously provided by Prof Dr R Fischer, Institute of Pathology, University of Cologne. The authors thank Mrs Martina Becker for her excellent technical assistance and Mrs Frances Wharton for editorial assistance.

1 Briozzo P, Badet J, Capony F, Pieri I, Montcourrier P, Barritault D. MCF-7 mammary cancer cells respond to bFGF and internalize it following is release for extracellular matrix: a permissive role of cathepsin-D. Exp Cell Res 1991;194:252-9.

2 Rochefort H. Cathepsin D in breast cancer: a tissue marker associated with metastasis. Eur 7 Cancer $1992 ; 28 \mathrm{~A} / 11$ : $1780-3$.

3 Vignon F, Capony F, Chambon M, Freis G, Garcia M, Rochefort $\mathrm{H}$. Autocrine growth stimulation of the MCF 7 breast cancer cell by estrogen-regulated $52 \mathrm{k}$ protein. Endocrinology 1986;118:1537-45.

4 Armas OA, Gerald WL, Lesser ML, Arroyo CD, Norton L, Rosen PP. Immunohistochemical detection of cathepsin $\mathrm{D}$ in T2NOMO breast carcinoma. Am $\mathcal{F}$ Surg Pathol 1994; 18:158-66.

5 Crombach G, Ingenhorst A, Göhring U-J, Möbius V, Peters $\mathrm{D}$, Schaeffer H-J, et al. Cathepsin D concentrations in cytosol of benignant and malignant tumors of the breast cytosol of benignant and malignant tumors of the breast

6 Crombach G, Ingenhorst A, Göhring U-J, Stützer H, Scharl A. Prognostic significance of cathepsin D in primary breast A. Prognostic significance of cathepsin D in prim

7 Granata G, Coradini D, Cappelletti V, Di Fronzo G. Prognostic relevance of cathepsin $D$ versus oestrogen receptors in node negative breast cancers. Eur $\mathcal{F}$ Cancer 1991;27: $970-2$

8 Isola J, Weitz S, Visakorpi T, Holli K, Shea R, Khabbaz N, et al. Cathepsin D expression detected by immunohistochemistry has independent prognostic value in axillary node negative breast cancer. $\mathcal{F}$ Clin Oncol 1993; 11:36-43.

9 Kute TE, Shao Z-M, Sugg NK, Long RT, Russell GB, Case LD. Cathepsin $\mathrm{D}$ as a prognostic indicator for node negative breast cancer patients using both immunoassays negative breast cancer patients using both immunoassa
and enzymatic assays. Cancer Res 1992;52:5198-203.

10 Spyratos F, Brouillet JP, Defrenne A, Hacene K, Rouesse J, Maudelonde TH, et al. Cathepsin D: an independent J, Maudelonde $\mathrm{TH}$, et al. Cathepsin $\mathrm{D}$ : an independent prognostic factor

11 Stonelake PS, Baker PG, Gillespie WM, Dunn JA, Spooner $\mathrm{D}$, Morrison JM, et al. Steroid receptors, $\mathrm{pS} 2$ and cathepsin D in early clinically node negative breast cancer. Eur 7 Cancer 1994;30A:5-11.

12 Tandon AK, Clark GM, Chamnes GC, Chirgwin JM, McGuire WL. Cathepsin D and prognosis in breast cancer. $N$ Engl f Med 1990;322:297-302.

13 Thorpe SM, Rochefort H, Garcia M, Freiss G, Christensen IJ, Khalaf S, et al. Association between high concentration of $\mathrm{Mr} 52,000$ cathepsin $\mathrm{D}$ and poor prognosis in primary breast cancer. Cancer Res 1989;49:6008-14.

14 Winstanley JHR, Leinster SJ, Cooke TG, Westley BR, PlattHiggins AM, Rudland PS. Prognostic significance of cathepsin-D in patients with breast cancer. $B r f$ Cancer 1993;67:767-72.

15 Westley B, Rocheford H. Estradiol induced proteins in MCF 7 human breast cancer cell line. Biochem Biophys Res Commun 1979;90:410-6.

16 Garcia M, Capony F, Derocq D, Simon D, Pau B, Rochefort $\mathrm{H}$. Monoclonal antibodies to the estrogen-regulated $\mathrm{Mr}$ 52000 glycoprotein: characterization an immunodetection in MCF7 cells. Cancer Res 1985;45:709-16.

17 Rochefort H, Cavailles V, Augereau P, Capony F, Maudelonde $\mathrm{T}$, Touitou I, et al. Overexpression and hormonal regulation of pro-cathepsin D in mammary and endometrial cancer. $\mathcal{F}$ Steroid Biochem 1989;34:177-82.

18 Capony F, Moreset M, Barret AJ, Capony JP, Brocqet $\mathrm{P}$, Vignon F, et al. Phosphorylation, glycosylation, and proteolytic activity of the 52-kDa estrogen-induced protein proteolytic activity of the 52-kDa estrogen-induced protein

19 Foucré D, Bouchet C, Hacén K, Pourreau-Schneider N, Gentile A, Martin PM, et al. Relationship between cathepsin D, urokinase, and plasminogen activator inhibitors in malignant vs benign breast tumours. Br $\mathcal{F}$ Cancer 1991; 64:926-32.

20 Garcia M, Salazar-Retana G, Pages A, Richer G, Domergue J, Pages AM, et al. Distribution of the Mr 52,000 estrogenregulated protein in benign breast diseases and other tissues by immunohistochemistry. Cancer Res 1986;46: 3734-8.

21 Faust PL, Kornfeld S, Chirgwin JM. Cloning and sequence analysis of cDNA for human cathepsin D. Proc Natl Acad Sci USA 1985;82:4910-4.

22 Maudelonde T, Brouillet JP, Roger P, Giraudier V, Pages $A$, Rochefort $\mathrm{H}$. Immunostaining of Cathepsin $\mathrm{D}$ in breast cancer: quantification by computerised image analysis and correlation with cytosolic assay. Eur f Cancer 1992;28A: 1686-91

23 Pujol P, Maudelonde T, Daures J-P, Rouanet P, Brouillet $\mathrm{J}-\mathrm{P}$, Pujol $\mathrm{H}$, et al. A prospective study of the prognostic value of cathepsin $\mathrm{D}$ levels in breast cancer cytosol. Cancer 1993;71:2006-12.

24 Duffy MJ, Reilly D, Brouillet J-P, McDermott EW, Faul C, O'Higgins $\mathrm{N}$, et al. Cathepsin D concentration in breast cancer cytosols: correlation with disease-free interval and overall survival. Clin Chem 1992;38:2114-6.

25 Remmele W, Sauer-Manthey J. Comparative biochemical and immunohistochemical studies on the cathepsin D content of human breast cancer. Virchows Arch [A] 1993; content of hum

26 Roger P, Montcourrier P, Maudelonde T, Brouillet JP, Pages $\mathrm{A}$, Laffargue $\mathrm{F}$, et al. Cathepsin D immunostaining in paraffin-embedded breast cancer cells and macrophages: correlation with cytosolic assay. Hum Pathol 1994;25: 863-71.

27 Veneroni S, Daidone MG, Di-Fronzo G, Cappelletti V, Amadori D, Riccobon A, et al. Quantitative immunohistochemical determination of cathepsin-D and its relation with other variables. Breast Cancer Res Treat 1993; 26:7-13.

28 Eng-Tan P, Benz CC, Dollbaum C, Moore DH, Edgerton SM, Zava DT, et al. Prognostic value of cathepsin D expression in breast cancer: immunohistochemical assessment and correlation with radiometric assay. Ann Oncol 1994;5:329-36.

29 Göhring U-J, Ingenhorst A, Crombach G, Scharl A. Kathepsin-D-Expression im primären MammakarzinomVergleich immunhistochemischer und biochemischer Ergebnisse. Pathologe 1993;14:313-7.

30 Scharl A, Vierbuchen $M$, Würz H. Immunhistochemischer Nachweis von Ostrogen-und Progesteronrezeptoren mit Hilfe monoklonaler Antikörper in Mammakarzinom geweben. Vergleich mit der biochemischen Rezeptoranalyse. Pathologe 1989;10:31-8.

$31 \mathrm{Hsu}$ S-M, Raisse L, Fanger H. Use of avidin-biotin-peroxidase-complex (ABC) in immunoperoxidase techoxidase-complex (ABC) in immunoperoxid

32 EORTC Breast Cancer Cooperative Group. Standards for the assessment of estrogen receptors in human breast cancer. Eur $\mathcal{F}$ Cancer 1973;9:379-81.

33 Lowry DH, Rosebrough NJ, Farr AL, Fandel RJ. Protein measurement with the folin phenol reagent. $\mathcal{F}$ Biol Chem 1951;193:265-75.

34 Peto R, Pike MC, Armitage P. Design and analyses of randomised clinical trials requiring prolonged observation of each patients: II. $B r \mathcal{F}$ Cancer 1977;35:1-39.

35 Cox DR. Regression models and life-tables. $\mathcal{F} R$ Stat Soc [B] 1972;34:187-200.

36 Mansour EG, Ravdin PM, Dressler L. Prognostic factor in early breast carcinoma. Cancer 1994;74:381-400.

37 McGuire WL, Tandon AK, Allred DC, Chamness GC Clark GM. How to use prognostic factors in axillary node nelark GM. How to use prognostic factors in axillary node 82:1006-15.

38 Rosner D, Lane WW. Should all patients with node negative breast cancer receive adjuvant therapy? Cancer 1991;68: 1482-94.

39 Early Breast Cancer Trialists' Collaborative Group. Systemic treatment of early breast cancer by hormonal, cytotoxic, or immune therapy. 133 randomised trials involving 31000 recurrences and 24000 deaths among 75000 women. Lancet 1992;339;1-15;71-85.

40 Garcia M, Lacombe MJ, Duplay H, Cavailles V, Deroca $\mathrm{D}$, Delarue JC, et al. Immunohistochemical distribution 
of the $52-\mathrm{kDa}$ protein in mammary tumors: a marker associated with cell proliferation rather than with hormone responsiveness. F Steroid Biochem 1987;27:439-45.

41 Mathieu M, Rochefort H, Barenton B, Prebois C, Vignon F. Interactions of cathepsin-D and insulin-like growth factor-II (IGF-II) on the IGF-II/Mannose-6-Phosphate Receptor in human breast cancer cells and possible consequences on mitogenic activity of IGF-II. Mol Endocrinol sequences on mito

42 Rochefort H, Capony F, Garcia M. Cathepsin D in breast cancer: from molecular and cellular biology to clinical 1990;2:383-8.

43 Henry JA, McCarthy AL, Angus B, Westley BR, May FEB, Nicholsin S, et al. Prognostic significance of the estrogenreglated protein, cathepsin $\mathrm{D}$, in breast cancer-an immunohistological study. Cancer 1990;65:265-71.

44 Têtu B, Brisson J, Côté C, Brisson S, Potvin D, Roberge N. Prognostic significance of cathepsin-D expression in node positive breast carcinoma: an immunohistochemical study. Int $\mathcal{F}$ Cancer 1993;55:429-35.

45 Visscher DW, Sarkar F, LoRusso P, Sakr W, Ottosen S, Wykes S, et al. Immunohistologic evaluation of invasionassociated proteases in breast carcinoma. Mod Pathol 1993; 6:302-6.

46 Namer M, Ramaioli A, Fontana X, Etienne M-C, Héry M, Jourlait $A$, et al. Prognostic value of total cathepsin D in breast tumors. Breast Cancer Res Treat 1991:19:85-93.

47 Seshadri R, Horsfall DJ, Firgaira F, McCaul K, Setlur V Chalmers $\mathrm{AH}$, et al. The relative prognostic significance of total cathepsin D and HER-2/neu oncogene amplification in breast cancer. Int $\mathcal{F}$ Cancer 1994;56:61-5.
48 Rogier H, Freiss G, Besse M-G, Cavalié-Barthez G, Garcia $M$, Pau B, et al. Two-site immunoenzymometric assay for the $52-\mathrm{kDa}$ cathepsin $\mathrm{D}$ in cytosols of breast cancer tissues. Clin Chem 1989;35:81-5.

49 Domagala W, Markiewski M, Kubiak R, Bartkowiak J, Osborn M. Immunohistochemical profile of invasive lobuOsborn M. Imm on the broch p53 protein negative, cathepsin D and oestrogen receptor p53 protein negative, cathepsin D and oestrog
positiv. Virchows Arch $[A]$ 1993;423:497-502.

50 Kandalaft PL, Chang KL, Ahn CW, Traweek ST, Meht Kandalaft PL, Chang KL, Ahn CW, Traweek ST, Mehta
P, Battifora H. Prognostic significance of immunohistochemical analysis of cathepsin D in low-stage breast cancer. Cancer 1993;71:2756-63.

51 Cowan WK, Angus B, Henry J, Corbett LP, Reid WA Horne CHW. Immunohistochemical and other features of breast carcinomas presenting clinically compared with those detected by cancer screening. Br f Cancer 1991;64: $780-4$.

52 Castiglioni T, Merino MJ, Elsner B, Lah TT, Sloane BF Emmert-Buck MR. Immunohistochemical analysis of cathepsins D, B, and L in human breast cancer. Hum Pathol 1994;25:857-62.

53 Martinet N, Beck G, Bernard V. Mechanism for the recruitment of macrophages to cancer site. In vivo concentration gradient of monocyte chemotactic activity. Cancer 1992;70:855-60.

54 Ravdin PM, Tandon AK, Allred DC, Clark GM, Fuqu SA, Hilsenbeck SH, et al. Cathepsin D by western blotting and immunohistochemistry: failure to confirm correlations with prognosis in node negative breast cancer. $7 \mathrm{Clin} \mathrm{Oncol}$ 1994;12:467-74. 